\title{
PENINGKATAN HASIL BELAJAR PENDIDIKAN AGAMA KRISTEN MELALUI METODE CARD SORT PADA SISWA KELAS IV SD NEGERI 163084 KOTA TEBING TINGGI
}

\author{
Junaisih Silalahi \\ Surel: junaisih.silalahi@gmail.com
}

\begin{abstract}
This aim of this research is to improve learning result on Christian Education through card sort method. This classroom action researchconducted by 2 cycles of the four phases: planning, implementation, observation, reflection. The subjects were students from class IV, SD Negeri163084 Tebing Tinggi which amounted to 12 students. This study used a qualitative descriptive analysis technique. The results showed that the use of the card sort method of Christian Education subjects can improve student learning result characterized by increased mastery learning students, namely the first cycle (75\%), cycle II (100\%) and complete learn the clasical equal to $100 \%$.
\end{abstract}

Keywords : Card Sort, Learning Result, Christian Education

\begin{abstract}
ABSTRAK
Penelitian ini bertujuan untuk meningkatkan hasil belajar siswa mata pelajaran Pendidikan Agama Kristen melalui metode card sort. Penelitian tindakan kelas ini dilaksanakan sebanyak 2 siklus dengan empat tahapan yaitu : perencanaan, pelaksanaan, observasi, refleksi. Subjek penelitian ini adalah siswa kelas IV SD Negeri163084 Tebing Tinggi sebanyak 12 siswa. Penelitian ini menggunakan teknik analisis dekriptif kualitatif. Hasil penelitian menunjukkan bahwa penggunaan metode card sort mata pelajaran PAK dapat meningkatkan hasil belajar siswa yang ditandai dengan peningkatan ketuntasan belajar siswa, yaitu siklus I (75\%), siklus II (100\%) dan dinyatakan berhasil secara klasikal $100 \%$.
\end{abstract}

Kata Kunci : Card Sort, Hasil Belajar, PAK

\section{PENDAHULUAN}

Pada dasarnya fungsi

Pendidikan Agama Kristen

dimaksudkan untuk menyampaikan

kabar baik (euangelion $=$ injil) yang disajikan dalam dua aspek, yaitu aspek Allah Tritunggal dan KaryaNya, dan aspek Nilai-nilai kristiani. Melalui pembelajaran pengetahuan agama akan terbentuk keterampilan beragama dan terwujud sikap beragama siswa. Sikap beragama yang diharapkan adalah sikap beragama yang utuh dan berimbang, mencakup hubungan manusia dengan Penciptanya dan hubungan manusia dengan sekitarnya. Untuk memastikan keseimbangan ini, pelajaran agama perlu diberi penekanan khusus terkait

Guru SD Negeri 163084 Tebing Tinggi 
dengan akhlak mulia atau budi pekerti.

Penjabaran kompetensi dalam pembelajaran PAK dirancang sedemikian rupa sehingga proses dan hasil pembelajaran PAK memiliki bentukbentuk karya, unjuk kerja dan pembiasaan pada perilaku/sikap yang merupakan bentuk-bentuk kegiatan belajar yang dapat diukur melalui penilaian (assessment) sesuai kriteria pencapaian setiap kompetensi dasar (Kemendikbud, 2013 : 15).

Masalah yang sering dihadapi pada mata pelajaran PAK di SD Negeri 163084 Tebing Tinggi adalah masih didominasi dengan pola klasik guru mata pelajaran PAK yang mengajarkan agama hanya sebagai rutinitas.Jumlah siswa yang sedikit dan alokasi jam pelajaran yang terbatas (2 jam) menyebabkan siswa kurang berminat untuk mengikuti pembelajaran PAK dan hanya mengejar nilai tanpa memahami dan mengimplementasikannya. Pelajaran PAK juga tidak termasuk mata pelajaran yang ikut dalam Ujian Negara dan dianggap bersifat teoritis, abstrak dan berbasis text book.Hal tersebut berdampak pada nilai PAK yang belum sesuai harapan.

Pembelajaran yang mengacu pada kurikulum yang berlaku dan pemiliham model pembelajaran yang tepat, dapat mengapresiasi dan mengakomodasi perbedaan individual peserta didik serta meningkatkan aktivitas dan hasil belajar peserta didik. Menurut Rachman (1997:151)

bahwa untuk menumbuhkan perhatian dan minat siswa, pembelajaran dapat dikembangkan melalui pendekatan pembelajaran terpadu.

$\begin{array}{rcr}\text { Setiap } & \text { guru } & \text { perlu } \\ \text { meningkatkan } & \text { peranan } & \text { dan }\end{array}$
kompetensinya, karena proses belajar mengajar dan prestasi belajar peserta didik sangat ditentukan oleh peranan dan kompetensi guru. Guru yang memiliki kompetensi baik akan mampu mengelola pembelajaran dengan baik sehingga prestasi belajar peserta didik juga bisa maksimal (Usman, 1998 : 9).

Permasalahan utama dari kondisi di atas adalah metode pembelajaran yang digunakan guru dalam kegiatan belajar mengajar PAK masih konvensional sehingga aktivitas dan hasil belajar peserta didik masih rendah. Oleh karena itu, diperlukan metode pembelajaran yang lebih menarik, salah satu diantaranya adalah dengan metode Card Sort. Metode ini merupakan kegiatan kolaboratif yang bisa digunakan untuk mengajarkan konsep pemnggolongan sifat, fakta tentang suatu objek atau mengulangi informasi.

Kegiatan pembelajaran melalui permainan dapat menciptakan suasana yang kondusif. Dengan bermain anak memperoleh pelajaran yang mengandung aspek kognitif, sosial, emosi dan perkembangan fisik. Melalui permainan anak dirangsang 
untuk berkembang secara umum, baik perkembangan berpikir, emosi maupun sosial (Ismail, 2006).

Metode card sort yaitu suatu strategi yang digunakan peserta didik dengan mengajak peserta didik untuk menemukan konsep dan fakta melalui klarifikasi materi yang dibahas dalam pembelajaran (Yasin, 2008). Pembelajaran aktif model card sort merupakan pembelajaran yang menekankan keaktifan siswa dimana dalam pembelajaran ini setiap siswa diberi kartu indeks yang berisi informasi tentang materi yang akan dibahas, kemudian siswa mendiskusikan dan mempresentasikan hasil diskusi tentang materi dan kategori kelompoknya.

Hisyam Zaini (2002: 51) ada beberapa kelebihan metode card sort antara lain sebagai berikut:

a. Siswa berperan secara aktif dalam proses pembelajaran.

b. Penilaian kepada siswa dilakukan secara otentik.

c. Proses kerja sama yang kuat antar siswa.

d. Siswa akan berpikir untuk kritis dalam menganalisis materi pembelajaran secara mandiri.

e. Siswa lebih mudah mengerti tentang materi yang diajarkan dari pada dengan menggunakan metode ceramah.

f. Siswa lebih antusias dalam pembelajaran.

g. Sosialisasi antara siswa lebih terbangun yakni antara siswa dengan siswa lebih akrab.
Penelitian Widyaningrum
(2012) menyimpulkan bahwa pembelajaran dengan menggunakan metode Card Sort dengan media Macromedia Flash dapat meningkatkan hasil belajar Biologi siswa kelas VIII H SMP Muhammadiyah 1 Surakarta tahun ajaran 2011/2012 pada aspek kognitif nilai awal sebesar $35,5 \%$, siklus I sebesar $64,5 \%$ menjadi $87,1 \%$ untuk siklus II, sedangkan pada aspek afektif siklus I sebesar 9,8 termasuk dalam kategori cukup berminat menjadi 13,4 termasuk dalam kategori berminat pada siklus II.

Melalui metode card sort tersebut diharapkan prestasi belajar PAK peserta didik dapat meningkat. Maka dari itu penulis ingin mengadakan penelitian tindakan kelas dengan judul "Peningkatan Hasil Belajar Pendidikan Agama Kristen Melalui Metode Card Sort Pada Siswa Kelas IV SD Negeri 163084 Tebing Tinggi Tahun Pelajaran 2014/2015.

Berdasarkan uraian pada latar belakang masalah, maka dapat dirumuskan permasalahan sebagai berikut: "Apakah dengan menggunakan pembelajaran metode card sort meningkatkan hasil belajar Pendidikan Agama Kristen di kelas IV SD Negeri 163084 Tebing Tinggi Tahun pelajaran 2014/2015?'

Tujuan dari penelitian ini adalah untuk meningkatkan hasil belajar Pendidikan Agama Kristenpada siswa kelas IV SD 
Negeri 163084 Tebing Tinggi tahun pembelajaran 2014/2015 melalui metode card sort.

\section{METODE PENELITIAN}

Penelitian ini dilaksanakan pada bulan April sampai dengan bulan Mei 2015 pada semester ganjil tahun ajaran 2014/2015. Penelitian ini dilaksanakan dalam 2 siklus. Peneliti mengambil lokasi penelitian tindakan kelas di SD Negeri 163084 Tebing Tinggi.

Subjek penelitian adalah siswa kelas IV SD Negeri163084 Tebing Tinggi dengan jumlah siswa sebanyak 12 orang dengan 7 orang laki-laki dan 5orang perempuan. Sumber data yang digunakan adalah siswa kelas IV SD Negeri 163084 dan teman sejawat. Pada Penelitian tindakan kelas data yang dikumpulkan dapat berbentuk kuantitatif maupun kualitatif. Data kuantitatif yang berupa nilai dianalisis dengan menggunakan analisis deskriptif komparatif yaiu membandingkan nilai tes kondisi awal, nilai tes setelah siklus I dan II yaitu nilai dari hasil ulangan harian siswa kelas IV SD Negeri 163084 pada siklus I dan II.

Metode penelitian yang digunakan dalam penelitian ini adalah Classroom Action Research atau penelitian tindakan kelas. Model penelitian tindakan kelas yang digunakan peneliti adalah sistem spiral refleksi diri yang dikembangkan oleh Kemmis dan
Taggart yang dimulai dengan perencanaan, tindakan, pengamatan, dan refleksi. Masing-masing siklus terdiri dari dua kali pertemuan yaitu sebagai berikut;

\section{Perencanaan}

Pada tahapan ini dilakukan berbagai persiapan dan perencanaan tindakan yang meliputi: menyusun skenario pembelajaran berupa Rencana Pelaksaan Pembelajaran, mempersiapkan media pembelajaran dan alat observasi, dan membuat instrumen untuk evaluasi yang berupa soal tes tertulis. Selain mempersiapkan hal-hal tersebut, untuk dapat melaksanakan penelitian ini dengan tujuan yang jelas peneliti juga perlu menetapkan indikator ketercapaian dalam penerapan metode card sort.

\section{Pelaksanaan}

a. Siklus I

Guru melakukan pembelajaran di dalam kelas dengan menggunakan panduan perencanaan yang telah dibuat. Siklus I dilakukan pada tanggal 6 Mei 2015. Tindakan pada siklus I ini dilakukan dengan menggunakan paduan perencanaan dan dalam pelaksanaannya bersifat fleksibel serta terbuka terhadap perubahan-perubahan. Guru mengajar dengan menggunakan RPP yang telah disusun dan dipersiapkan sebelumnya. Sedangkan, peneliti dengan bantuan teman mengamati 
pelaksanaan tindakan dengan menggunakan lembar observasi yang telah dipersiapkan sebelumnya. Peneliti sebagaiu guru memberikan kartu dengan pertanyaan tentang Allah tri tunggal dan karya-karyaNya, dan nilai-nilai kristiani serta wujud tindakan manusia yang sepenuhnya bergantung pada Allah.

\section{b. Siklus II}

Guru melakukan pembelajaran di dalam Guru melakukan pembelajaran di dalam kelas dengan menggunakan panduan perencanaan yang telah dibuat. Siklus I dilakukan pada tanggal 13 Mei 2015. Pelaksanaan tindakan pada siklus II ini juga sama dengan siklus I namun mengalami perbaikan menuju lebih baik lagi.

Berdasarkan perencanaan yang telah dibuat guru melaksanakan tindakan pembelajaran dengan penerapan belajar tuntas, sedangkan peneliti bertugas melakukan observasi pada saat pelaksanaan tindakan.Siswa juga dapat berinteraksi kepada guru secara langsung, bebas, sesuai kondisi nyata dan menyenangkan. Pada saat kegiatan pembelajaran berlangsung guru sebagai peneliti dibantu oleh para observer lainnya untuk melakukan pengamatan, pendokumentasian, selain itu peneliti bertindak sebagai fasilitator, motivator dan sekaligus sebagai observatory.
3. Observasi/Pengamatan

Observasi adalah usaha merekam semua peristiwa dan kegiatan yang terjadi selama tindakan berlangsung. Observasi itu harus bersifat terbuka pandangan dan pikirannya. Pelaksanaan pengamatan melibatkan beberapa pihak diantaranya guru, peneliti, dan teman sejawat. Pelaksanaan observasi dilakukan pada saat proses pembelajaran berlangsung dengan berpedoman pada lembar observasi yang telah dibuat oleh peneliti. Dalam kegiatan pembelajaran, peneliti melakukan pengamatan dengan pengambilan data hasil belajar dan kinerja siswa. Hal tersebut antara lain:

a. Kegiatan siswa selama kegiatan pembelajaran PAK.

b. Ketuntasan belajar siswa dalam mengerjakan post test.

d. Refleksi

Data yang diperoleh pada lembar observasi, dianalisis secara lebih dalam dan tajam pada siklus ke dua ini. Kemudian dilakukan refleksiatau perenungan. Pelaksanaan refleksi merupakan hasil observasi/ pengamatan peneliti pada saat melakukan observasi di kelas dan lingkungan sekolah yang bertujuan untuk mengevaluasi hasil tindakan yang telah dilakukan yaitu dengan menerapkan metode pembelajaran card sort.

Instrumen yang digunakan dalam penelitian ini adalah pedoman observasi, test hasil belajar, dan wawancara. Data aktivitas belajar dan 
kendala yang dihadapi selama proses pembelajaran dikumpulkan melalui observasi (lembar observasi terlampir). Hal-hal yang akan diobservasi adalah kegiatan lisan, kegiatan metrik, kegiatan emosional. Data hasil observasi, dan data hasil wawancara yang jenis datanya berupa pernyataan-pernyataan, dianalisis dengan menggunakan teknik analisis statistik deskriptif.

Metode pengumpulan data penelitian ini adalah tertulis dan observasi. Penelitian ini dikatakan berhasil apabila siswa telah memperoleh nilai ketuntasan secara klasikal minimal $85 \%$ dari jumlah siswa dengan rumus sebagai berikut :

Persentase Ketuntasan klasikal $=$ Jumlah siswa yang tuntas $\times 100 \%$ Jumlah siswa yang mengikuti tes

\section{HASIL DAN PEMBAHASAN}

Peneliti telah melakukan penelitian menggunakan metode pembelajaran teknik card sort untuk meningkatkan kualitas pembelajaran mata pelajaran PAK pada siswa kelas IV SDN 163084 Tebing Tinggi melalui dua melalui dua siklus. Sebelum dilakukannya siklus I terlebih dahulu peneliti melakukan tes awal. Tes awal juga dilaksanakan untuk menentukan penelitian dapat dilanjutkan atau tidak, hal ini dapat dilihat dari hasil yang diperoleh dari tes awal adalah dari 12 siswa, hanya 100 siswa yang memenuhi nilai ketuntasan belajar (nilai 70) dan masih terdapat 2 siswa yang tidak memenuhi nilai ketuntasan. Persentase ketuntasan belajar hanya $66,67 \%$.

Hasil penelitian tindakan kelas menunjukkan bahwa pengamatan yang dilakukan oleh mitra kolaborasi dan peneliti pada aktivitas guru dan siswa melalui penerapan metode card sort pada mata pelajaran Pendidikan Agama Kristen kelas IV SD Negeri 163084 Tebing Tinggi dapat dilihat Junaisih Silalahi: Peningkatan Hasil Belajar...

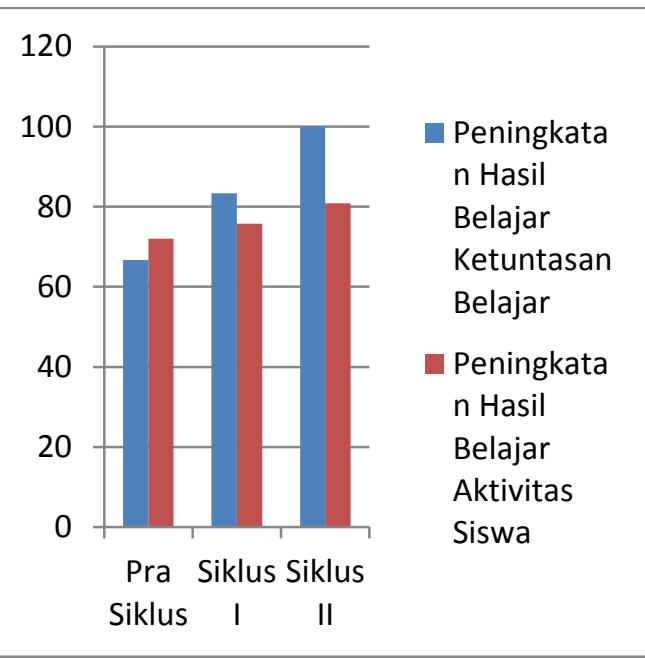

Gambar 1. Peningkatan Hasil Belajar Siswa Pra Siklus, Siklus I dan II

Berdasarkan pengamatan peneliti dari tindakan pra siklus, siklus I dan II terjadi peningkatan hasil belajar pada jumlah siswa dan persen ketuntasan belajar secara klasikal. Pembelajaran siklus I menggunakan metode card sort menunjukkan adanya peningkatan hasil belajar siswa. Hasil analisis data 
nilai keterampilan siswa mengenai materi pelaran pada tes siklus I dan menunjukkan bahwa persentase hasil tes siswa yang belajar tuntas naik sebesar $16,67 \%$ dibandingkan dengan siklus I.

Tindakan siklus I dengan menggunakan teknik card sort, pada materi wujud tindakan manusia yang bergantung sepenuhnya pada Allah. Pada umumnya siswa sudah menguasai materi pelajaran dengan baik. Hal ini terlihat pada pencapaian nilai rata-rata post tes mengalami peningkatan dari siklus I sampai siklus II. Nilai rata-rata kelas pembelajaran siklus I menunjukkan peningkatan bila dibanding dengan pra tindakan ke siklus I, yaitu dari 70,5 menjadi 74,75. Persentase aktivitas belajar siswa pada siklus I yaitu $75,8 \%$. Nilai maksimal kelas adalah 88 dan nilai minimal 65 . Sementara persentase ketuntasan belajar siswa yang telah mencapai KKM dari pra tindakan meningkat dari $75 \%$ menjadi $83,33 \%$ pada siklus I

Pada siklus I ini sudah terjadi peningkatan perhatian dan penguasaan materi siswa, yaitu berada pada kategori sedang. Namun tingkat motivasi dan tingkat perhatian siswa masih rendah dan perlu untuk ditingkatkan lagi. Hal ini disebabkan kurangnya komunikasi dan interaksi yang baik antar siswa dan perlu diperhatikan dalam pelaksanaan pembelajaran siklus II. Hal-hal yang dianggap kurang pada siklus I seperti perlu adanya dialog yang lebih santai agar siswa lebih terbuka dan tidak sungkan dalam mengeluarkan pendapat, memberikan motivasi pada siswa serta pengoptimalan belajar diperbaiki pada siklus II.

Pada siklus II persentase ketuntasan hasil belajar siswa yaitu $100 \%$. Aktivitas belajar siswa sebesar $80,9 \%$. Peningkatan hasil belajar meningkat sebesar $16,67 \%$ dari siklus I ke siklus II. Setelah mendapatkan metode pembelajaran teknik card sort, siswa sudah terlihat terdapat peningkatan keaktifan dan ketepatan dalam menemukan pasangan jawaban yang tepat. Selain itu, pola komunikasi dan interaksi antar siswa dalam menjawab dan memecahkan permasalahan dan pertanyaan dari peneliti sudah terjalin dengan baik. Meskipun tidak menutup kemungkinan masih ada kekurangan, namun tujuan dari pembelajaran yang diharapkan dapat tercapai.

Pada siklus I hasil belajar belum bisa dikatakan berhasil karena belum memenuhi kriteria ketuntasan. Hal tersebut dikarenakan pada saat pelaksanaan pembelajaran ada beberapa siswa yang pasif, karena Banyak siswa ragu - ragu dan kurang percaya diri untuk bertanya, memberi pendapat, dan menjawab pertanyaan. Selain itu Suasana kelas ramai dan banyak siswa yang tidak memperhatikan penjelasan guru maupun memperhatikan teman atau siswa lain yang mengeluarkan 
pendapat. Hasil refleksi yaitu berupa temuaan tingkat keefektifan desain pembelajaran dengan menggunakan metode pembelajaran card sort dengan penjelasan awal di kelas sebelum observasi dengan jelas dan pendampingan yang maksimal dalam kegiatan-kegiatan siswa dan daftar permasalahan yang muncul dilapangan dituangkan kembali kedalam rancangan tindakan berikutnya, selanjutnya tindakan refleksi terhadap rancangan yang telah disusun kembali sebelum digunakan.

Siklus II ditujukan untuk memperbaiki kekurangan yang terjadi pada siklus I berdasarkan hasil refleksi siklus I. Dalam perbaikan ini diharapkan siswa menjadi lebih aktif dalam proses pembelajaran dan hasil belajar siswa dapat meningkat sesuai target yang akan dicapai. Pada siklus II ini ada peningkatan dan ketertarikan siswa untuk belajar PAK sehingga proses pembelajaran berlangsung baik dan menyenangkan.

Siswa sudah terlihat terdapat peningkatan keaktifan dan

ketepatan dalam menemukan pasangan jawaban yang tepat.

Penggunaan

metode

pembelajaran teknik card sort melibatkan pembelajaran aktif pada siswa. Hasil yang diperoleh telah mencapai lebih dari batas minimal indikator keberhasilan sehingga penelitian tidak perlu dilanjutkan lagi untuk siklus berikutnya. Hal ini sesuai dengan pendapat Ismail (2008) yang menyatakan bahwa metode card sort juga merupakan salah satu metode atau strategi pembelajaran aktif, inovatif, kreatif, efektif dan menyenangkan yang bertujuan untuk mengaktifkan individu sekaligus kelompok dalam belajar.

Kelebihan dari metode pembelajaran questioning teknik card sort yaitu menjadi pembelajaran menyenangkan dan siswa tidak merasa bosan. Dapat mengaktifkan siswa dalam hal bertanya, menjawab pertanyaan maupun menyampaikan pendapat. Hasil belajar siswa mengalami peningkatan, ini terlihat pada hasil nilai setiap siklus makin meningkat. Hal ini sesuai pendapat Hisyam Zaini (2002: 51) ada beberapa kelebihan metode cardsort antara lain sebagai berikut : Siswa berperan secara aktif dalam proses pembelajaran, Penilaian kepada siswa dilakukan secara otentik, membantu siswa berpikir untuk kritis, Sosialisasi antara siswa lebih terbangun.

Hasil observasi kegiatan siswa sudah termasuk ke dalam kategori baik, berarti disini peneliti sudah mulai memilimalisir kekurangan sebelumnya. Kegiatan siswa dalam memecahkan masalah dalam kelompok, berdiskusi dengan teman sebangku, dapat berupa saling berbagai jawaban, mempresentasikan hasil diskusi dengan teman sebangkunya di depan kelas mengalami peningkatan dari siklus 
sebelumnya. Sehingga dianggap sudah cukup baik oleh peneliti dan pengamat.

Dari kegiatan pembelajaran yang telah berlangsung dengan penerapan metode card sort, maka tujuan pembelajaran yaitu untuk dapat mengatasi kesulitan belajar siswa dan siswa untuk lebih aktif, kreatif dalam proses belajar-mengajar. Pada kegiatan siklus kedua, menunjukkan bahwa tidak ada permasalahan dalam perumusan perencanaan tindakan (RPP). Hal tersebut sesuai dengan pendapat Yasin (2008), metode card sort yaitu suatu strategi yang digunakan peserta didik dengan mengajak peserta didik untuk menemukan konsep dan fakta melalui klarifikasi materi yang dibahas dalam pembelajaran

Berdasarkan hasil yang didapat dari setiap siklus proses pembelajaran yang optimal, hal ini ditunjukkan dengan meningkatnya penguasaan materi dan hasil belajar siswa. Oleh karena itu dapat disimpulkan bahwa proses pembelajaran dengan penerapan metode card sort sangat sesuai dengan mata pelajaran PAK. Maka dari itu, Penelitian Tindakan Kelas (PTK) ini bisa dikatakan berhasil karena hasil peningkatan proses pembelajarannya optimal.

\section{SIMPULAN}

Dari hasil temuan penelitian tentang hasil belajar siswa dengan metode card sort di kelas IV SD
Negeri 163084Tebing Tinggi tahun pelajaran 2014/2015 berdampak positif dalam meningkatkan hasil belajar siswa mata pelajaran PAK. Hal tersebut dapat dilihat dari peningkatan persentase ketuntasan belajar siswa pada siklus I $(83,33 \%)$ dan siklus II (100 \%).

Atas dasar simpulan dan implikasi hasil penelitian tindakan kelas di atas, penulis memberikan saran-saran sebagai berikut :

1. Bagi Sekolah

Sekolah perlu memberikan dukungan kepada guru dalam menambah wawasan dan meningkatkan keterampilan dalam mengajar agar keberhasilan dalam proses pembelajaran di kelas tercapai. Dengan demikian guru akan mengetahui keberhasilan dan kekurangan pembelajaran yang telah dilakukannya.

\section{Bagi Guru}

Guru juga diharapkan untuk meningkatkan kualitas proses pembelajaran, memilih bahan atau media pembelajaran yang baik, dan meningkatkan efisiensi dan efektifitas waktu pembelajaran.

\section{Bagi Siswa}

Siswa lebih giat dalam belajar dan tidak malu atau takut bertanya kepada guru tentang materi yang masih kurang dipahami atau kurang jelas, dan disarankan untuk dapat menghargai pertanyaan atau jawaban yang diajukan teman 


\section{DAFTAR RUJUKAN}

Ismail, A. 2006. Education Games : Menjadi Cerdas dan Ceria Dengan Permainan Edukatif. Yogyakarta: Pilar Media.

Kemendikbud. 2013. Pendidikan Agama Kristen dan Budi Pekerti: buku guru/ Kementerian Pendidikan dan Kebudayaan. Jakarta: Kementerian Pendidikan dan Kebudayaan.

Rachman, M. 1997. Manajemen Kelas. Semarang: Departemen Pendidikan dan Kebudayaan Direktorat Jenderal Pendidikan Tinggi Proyek PGSD.

Usman, M. U. 1998. Menjadi Guru Profesional. Bandung: Remaja Rosdakarya.

Widyaningrum, L. 2012. Penerapan Metode Pembelajaran Card Sort Dengan Macromedia Flash Untuk Meningkatkan Hasil Belajar Biologi Materi Sistem Gerak Pada Tumbuhan Kelas VIII HSMP Muhammadiyah 1 Surakarta Tahun Ajaran 2011/2012. Universitas Muhammadiyah Surakarta.

Yasin, A. F. 2008. Dimensi Pendidikan Islam. Malang: UN Press.

Zaini Hisyam. 2002. Strategi Pembelajaran Aktif di Perguran Tinggi. Yogyakarta: PT.CTSD. 